\title{
NIH panel urges technology transfer reforms
}

Current negotiations over intellectual property rights are "burdensome," and "current trends pose a serious threat" to biomedical research and development, says a Working Group on Research Tools. The panel of seven outside experts was appointed by the NIH (Bethesda, MD) to make recommendations. The action came following mounting complaints from both academic and industry researchers that owners of rights to research tools are increasingly reluctant to freely share them, instead demanding legal agreements that result in time-wasting "haggling" over potential profits.

The report identifies federal law and common business practice as culprits in both $\mathrm{NIH}$-funded academic institutions and private companies, and recommends the $\mathrm{NIH}$ revise current guidelines to promote freer circulation of research tools via use of standardized technology-transfer agreement forms. In addition, some panel members blame the underlying problem on "excessively broad patent claims," resulting from Patent Office decisions and court rulings, and urge a major review of the way patent law is applied in biotechnology. At issue is the potential commercial value of research tools-such as biomedical technologies and products as reagents, monoclonal antibodies, cell lines, animal models, combinatorial chemistry libraries, clones, and such cloning tools as PCR, lab methods and machines, and even DNA sequences.

Before compiling the report, the Working Group solicited comment from three main groups: bench scientists (from academia and industry), technology-transfer managers from NIH-funded universities, and private firms. The most extensive responses came from universities, which submitted samples of license and transfer agreements they found objectionable. Private sector comments were funneled through the trade association Biotechnology Industry Organization (Washington, DC), which sent more than 100 questions to member biotechnology firms but received only a $10-15 \%$ response. Although complaints were widespread and sometimes vehement, there was no agreement on cause, just reciprocal finger-pointing between the three key groups.

"Many companies [nonprofit and industry] seek unreasonable levels of control over new inventions. ..." says the report. For example, the panel received complaints from scientists about access to powerful "cre-lox

Neil Swan is a freelance writer working in Falls Church, VA. recombination" technology that allows precise genetic modifications that target only a single specific tissue. Although the technology was originally available without licensing, DuPont (Wilmington, DE), which owns the patent, now requires researchers to buy or negotiate a license. Brian Sauer of the NIH, who developed the technology as a DuPont scientist, says DuPont is simply following common market practice, which has changed over the last few years.

Other complaints concern expressed sequence tags (ESTs), partial-sequences from cDNA libraries, which are used to identify gene sequences or as probes for cloning full genes. According to panel member Stephen Holtzman, chief business officer of Millennium Pharmaceuticals (Cambridge, MA), university researchers would like to search EST databases compiled by private companies, but some companies are demanding a license on anything found, which he says "disturbs some researchers."

If private companies are too free in sharing their biotechnology "crown jewels" with other institutions, they risk loss of future profits, the panel acknowledged. "It's not about patents and it's not about greed," says Holtzman. "Companies must make judgments about terms and conditions. For very valuable assets, I must remember my legal responsibility to my company and its stockholders."

"Some scientists complain that too many lawyers are getting involved with too many negotiations," says Rebecca Eisenberg, law professor at the University of Michigan Law School (Ann Arbor, MI) and chair of the Working Group. "Increasingly, there is an overlap between commercial interests and basic research interests of different institutions with different agendas. Each side now sees the other as a potential influence on their competitive position."

Industry scientists complain that some universities actually discriminate against forprofit companies, making discoveries more readily available to academia. "Industry scientists find it unfair that their own use of taxpayer-funded research tools should have to await protracted negotiations over terms, particularly when the same tools are freely available to academic scientists," says the report.

University lawyers and technology-transfer experts argue that they are only complying with federal law and NIH guidelines: The 1980 Bayh-Dole Act directs universities to promote commercial development of discoveries made with NIH funds. The reasoning behind this was to maintain control of taxpayer-funded discoveries and to seek profits, when appropriate, for the universities that make the discoveries. However, although current NIH guidelines are based on and support the law's objectives, they are subject to interpretation, says panel member John Barton, who notes that some universities have adopted policies significantly more restrictive than others.

Among its recommendations, the Working Group suggests the NIH should: (1) promote freer circulation of research tools (regardless of source) without negotiations and legal agreements whenever possible, especially when there is no obvious commercial value and the prospect of profit is remote; (2) promote the use of standard agreement forms by developing a single standardized Material Transfer Agreement (MTA); and (3) develop and promote guidelines for recipients of $\mathrm{NIH}$ funds on what terms are reasonable in licenses and MTAs, both for importing and exporting research tools (www.nih.gov/news/researchtools/index.htm).

NIH last year stepped into the academiaindustry fray only because no other agency has this clear-cut role. In a largely unregulated marketplace of biotechnology knowledge, NIH has no real power over private industry and no authority to dictate terms of access to these tools, but it is seen as the only institution in a position to set examples, influence reform, and establish marketplace precedents to ease exchanges.

Importantly, the panel notes that "excessively broad patent claims" resulting from Patent Office decisions and court rulings have significantly contributed to restrictions on access to research tools. The US Patent Office is currently considering controversial applications to patent broad EST claims, which one panel member said would be unreasonably sweeping if they extend to any protein that has the EST as part of its sequence (see "Patent office resurrects EST debate," p. 711).

In addition, two panel members, in a minority statement in the report, urge a major review of the way patent law is applied in biotechnology in order to prevent overly broad patent claims. Barton, a law professor at Stanford University (San Francisco, CA), says concern may focus too much on MTAs. "I see those MTAs as sometimes reflecting rights created by the patent law. We should ask whether the patent law is defining intellectual rights in the correct way."

Harold Varmus has directed NIH officials to review and implement, probably early next year, the panel's proposed guidelines for reviewing and standardizing technologytransfer policies of NIH funding recipients.

Neil Swan 